\title{
Risk Assessment and Consequences of Retained Placenta for Uterine Health, Reproduction and Milk Yield in Dairy Cows
}

\author{
László Könyves ${ }^{1}$, Ottó Szenci ${ }^{2}$, Viktor Jurkovich ${ }^{1}$, Lászlóné Tegzes ${ }^{1}$, Attila Tirián ${ }^{1}$, \\ Norbert Solymosi ${ }^{3}$, Gyula Gyulay ${ }^{4}$, Endre Brydl ${ }^{1}$ \\ ${ }^{1}$ Department of Animal Hygiene, Herd Health and Veterinary Ethology, Faculty of Veterinary Science, \\ Szent István University, Budapest, Hungary \\ ${ }^{2}$ Clinic for Large Animals, Faculty of Veterinary Science, Szent István University, Üllő, Hungary \\ ${ }^{3}$ Department of Biomathematics and Informatics, Faculty of Veterinary Science, Szent István University, \\ Budapest, Hungary \\ ${ }^{4}$ Private Veterinarian, Martonvásár, Hungary
}

Received June 2, 2008

Accepted November 12, 2008

\begin{abstract}
The objective of the study was to determine the value of metabolic indicators characterising the energy and acid-base metabolism of dairy cows for predicting the risk of retained placenta (RP). The connection between RP and different factors analysed, and the effect of RP on the development of puerperal metritis (PM) as well as on reproduction and milk production was studied. A total of 105 Holstein-Friesian cows were included and sampled between days -14-0 prepartum and then on days $4,10-14,28-35,56-63$ and 84-91 postpartum, for metabolic tests. From day 4, at times coinciding with the days of metabolic sampling, uterine involution and metritis were monitored by clinical examination, and from days 28-35 ovarian activity was monitored by ultrasonography. On days $-14-0$, the plasma non-esterified fatty acids (NEFA) concentration showed a positive Odds Ratio (OR) 102.1, $P<0.05$; while urinary net acid-base excretion (NABE) exhibited a negative correlation (OR $0.99 ; P<0.05$ ) with the odds of RP. NEFA and NABE were negatively correlated (Pearson's coefficient: $-0.24 ; P<0.05$ ). Ketonuria of grade $\geq 2+$ increased the probability of RP (OR: Infinite; $P<0.05)$. On day $-14-0$ prepartum, elevated plasma NEFA concentration, decreasing urinary NABE and grade $\geq 2+$ ketonuria indicates a higher risk of RP. The odds of RP were not influenced by parity, sex and viability of the calf, and the calving assistance. RP increased the risk of PM (OR: 27.3; $P<0.0001)$. The $\mathrm{RP}$ alone did not exert an influence on the metabolic status, reproductive performance or milk production of cows.
\end{abstract}

Risk indicators, energy balance, acid-base metabolism, milk production

In recent decades, the milk production of dairy cows has increased steadily, while their reproductive performance has declined. This is mostly due to production diseases, commonly occurring in the peripartal period (Brydl et al. 2003, 2008; Ingvartsen 2006; Thatcher et al. 2006). Retained placenta (RP) is an important disorder of dairy cows, which occurs in 4 to $18 \%$ of calvings (Han and Kim 2005). The aetiology of RP is not completely clear. Factors contributing to its occurrence include calving-related factors such as dystocia, stillbirth, twinning, length of gestation (Correa et al. 1993; Han and Kim 2005), parity (Correa et al. 1993), and certain nutritional problems (Laven and Peters 1996). In other cases, no association was found between dystocia (Curtis et al. 1985), parity (Han and Kim 2005) and the development of RP. Oxidative stress may contribute to RP as well. For this reason, the beneficial effect of adequate supplementation with known nutrients (e.g. selenium, zinc, copper, iron and vitamin E, A and C, etc.) required for antioxidant defence has been reported in some (Trinder et al. 1973; Harris on et al. 1984; Miller et al. 1993), but not all (Hidiroglou et al. 1987; Stowe et al. 1988) previous studies.

Few data are available on the role of metabolic status preceding the development of RP, more specifically, the disturbances of energy balance and acid-base metabolism as

Address for correspondence:

Dr László Könyves

Szent István University

Faculty of Veterinary Science

H-1078 Budapest, István u. 2

Hungary

Phone: +36 14784242

Fax: +361478 4243

E-mail: Konyves.Laszlo@autk.szie.hu

http://www.vfu.cz/acta-vet/actavet.htm 
risk factors for RP. It is known that in the peripartal period, dairy cows have a negative energy balance (NEB). The available energy amount depends on the dry matter intake and utilisation, the latter being determined by the rumen microflora (Grummer 1995) and adaptive changes of the ruminal epithelium, which depend on the acid-base conditions within the rumen (Dirksen et al. 1999). Optimally, the majority of cows adapt to the NEB over a longer period of time during a multi-step process consisting of a series of physiological, metabolic and endocrine changes (Ingvartsen 2006). This adaptation process can be followed with the help of indicators such as plasma non-esterified fatty acids (NEFA), acetoacetic acid (AcA), certain metabolic hormones, urinary net acid-base excretion (NABE) (Huszenicza et al. 2002; Brydl et al. 2003; Jorritsma et al. 2003). Deviations from the physiological range indicate disturbances of this adaptation mechanism and, therefore, they can be defined as risk factors or risk indicators.

NEB may develop already at the end of gestation (Brydl et al. 2003, 2008; Grummer et al. 2004) and it may contribute to the development of many production diseases such as the fatty liver syndrome and ketosis (Bertics et al. 1992), dystocia (Zamet et al. 1979), or immunosuppression (Goff 2003). Overcondition (Hayirli et al. 2002) as well as management defects and environmental factors resulting in reduced dry matter intake increase the risk of development of prepartum NEB (Grummer et al. 2004). RP has a decisive role in the development of metritis (Kaneene 1995), but ketosis occurring at the early stage of lactation is also a major risk factor (Huszenicza et al. 1998). RP increases the risk of fatty liver syndrome and ketosis (Han and Kim 2005); the latter, in turn, delays the postpartum resumption of cyclic ovarian function and prolongs the interval from calving to first ovulation (Huszenicza et al. 1998; Opsomer et al. 2000). RP and puerperal metritis $(\mathrm{PM})$ prolong the interval from calving to first service and conception and decrease the conception rate (Maizon et al. 2004; Han and Kim 2005).

Few sources are available in the literature on strategies for the prevention of production diseases. Early diagnosis and prevention require a thorough knowledge of the risk factors predisposing to their development (Jorritsma et al. 2003; Ingvartsen 2006; Mulligan et al. 2006).

The objective of this study was to obtain a better understanding of the above risk factors predisposing cows to production diseases. Certain metabolic indicators may be suitable for predicting the risk of RP and serve as a basis for the development of preventive and monitoring strategies for practice. For this reason, the correlations between RP and indicators characterising the energy balance and acid-base status of dairy cows as well as certain environmental and animal-dependent predisposing factors were studied. In addition, the effects of RP on the development of puerperal metritis as well as on metabolic status, reproductive performance, and milk production were analysed.

\section{Materials and Methods}

Characteristics of the herd studied

The farm serving as the study site had a dairy herd comprising 730 Holstein-Friesian cows. Milk production of the 305-day lactation was $8,000 \mathrm{~kg}$, with $3.6-3.7 \%$ butterfat and $3.1-3.2 \%$ milk protein content. In the previous year, the calving interval was 433 days, the calving to conception interval was 168 days, the number of services per conception was 3.3, the interval from calving to first service was 97 days, and the pregnancy rate to first service was $43 \%$. The rate of losses due to mortality, and emergency slaughter was $9.7 \%$, and the total sorting out rate was $31.4 \%$. The farm used loose housing system and the cows were kept in groups, in houses with deep litter and having outdoor pens. Groups were formed by considering the serial number of lactations, the milk production level, and the lactation and pregnancy status of the cows. The calving barn was of loose system, with the cows kept in small groups. In the two weeks before calving, in the calving barn and in the first month of lactation the primiparous and multiparous cows were kept together, while from the peak of lactation they were kept in separate groups. The daily ration fed to cows was formulated with the help of a ration-optimising programme (AminoCow 3.0), by taking into consideration the composition of forages determined by feed analysis, the lactation and pregnancy status, the milk production, and the body condition score. The calculated nutrient content of the total mixed ration (TMR), distributed to the cows twice a day met the requirements (NRC, 2001). 
Study design

A total of 105 clinically healthy Holstein-Friesian cows two weeks before the expected calving were included in the study series. The studies comprised the following elements:

Metabolic tests

To study the energy balance and acid-base status, blood and urine samples were taken for laboratory tests. The samples were taken 3-5 h after the morning feeding. Blood samples were taken from the vena epigastrica superficialis into test tubes containing $0.05 \mathrm{ml}$ sodium heparin as anticoagulant. Urine samples were obtained by catheterisation of the urinary bladder. The samples were kept at $+4{ }^{\circ} \mathrm{C}$ and transported to the laboratory within $4 \mathrm{~h}$. Samples were taken on day $-14-0$ before calving and on days $4,10-14,28-35,56-63$ and 84-91 postpartum.

Test indicators and methods

Energy metabolism

Blood plasma: acetoacetic acid (AcA): specific spectrophotometric determination by diazotation of the compound; non-esterified fatty acids (NEFA) by photometric method (Unicam Helios Gamma, Unicam Ltd., UK); aspartate aminotransferase (AST) activity (Human 12021); glucose (G) (Human 10121) (Autohumalyzer 900 S Plus, Human GmbH, Germany).

Urine samples: AcA: semi-quantitative determination using a reagent strip containing sodium nitroprusside (Ketostix ${ }^{\circledR}$, Bayer Corp., USA).

Body condition score (BCS): 5-point condition scoring system (Mulvany 1977).

Acid-base metabolism: Urine pH (Radelkis OP211/1, Radelkis, Hungary); net acid-base excretion (NABE): titrimetric method (Kutas 1965).

Clinical examinations and data collection related to calving and health status

The data on parity, date of calving and the use of calving assistance ( 0 : no; 1 : yes), viability ( 1 : normal; 2 : dead calf; 3: mortality in $24 \mathrm{~h}$ ) and sex (1: male; 2 : female) of the calf were recorded with the use of codes marked in brackets here. During the first 14 days postpartum, the rectal temperature and the clinical diseases were recorded daily. Retained placenta was diagnosed if spontaneous expulsion of the foetal membranes did not occur within $24 \mathrm{~h}$ after calving.

Monitoring uterine health and involution

To diagnose puerperal metritis and to monitor uterine involution, rectal and clinical examinations were performed on days $4,10-14$ and 28-35 postpartum.

Diagnosis of puerperal metritis, definitions

Puerperal metritis (PM) was diagnosed if on days 4 or 10-14 postpartum the uterus contained a large volume of foul-smelling, reddish-brown, dilute discharge mostly containing necrotic tissue debris (putrid discharge) and the uterine wall had become thinner than normal. A similar diagnosis was established in cases when there was less abundant, putrid, purulent uterine discharge but the wall of the uterus was thickened and oedematous. The disease may be accompanied by fever $\left(\geq 39.5^{\circ} \mathrm{C}\right)$ and systemic signs (dullness, lack of appetite), as well (Sheldon and Dobson 2004; Sheldon et al 2006).

Characterisation of uterine involution

To characterise the anatomical involution of the uterus, a scoring system (U1-U3 score) was used (Becze and Wekerle 1980) on days $28-35$ postpartum as follows:

U1: the uterus is of normal shape and tone, indicative of an involution of normal course; the uterus becomes erect at oestrus. U2: the uterus is slightly enlarged, has slightly descended towards the abdominal cavity, it is flaccid, pasty to touch. There may be abnormal catarrhal discharge in its lumen. This is indicative of mild subinvolution. U3: the uterus is enlarged, has descended into the abdominal cavity, it is flaccid and palpable, sometimes with abnormal content. This is indicative of severe metritis and parametritis, pyometra, and severe subinvolution. The transition forms were scored with 0.5 accuracy. Subinvolution was diagnosed if on days 28-35 postpartum the uterine score was $\geq 2$.

Study of the ovaries and the oestrous cycle

In order to characterise ovarian function and the structures present on the ovaries, rectal examination of the ovaries was performed on days 28-35, 56-63 and 84-91 postpartum using an ultrasound scanner (ALOKA 7.5 MHz). The presence of follicles representing various stages of development (F1 - 3, 2-5 mm to $10-18 \mathrm{~mm}$ ), a developing or florescent corpus luteum (CL) or a regressive corpus luteum (RCL) was studied. The presence of follicular cysts (a fluid-filled, thin-walled structure $>20 \mathrm{~mm}$ in diameter) and luteal cysts (a thick-walled structure containing a fluidfilled cavity) was also studied and recorded. Ovarian function was considered cyclic if a CL or RCL was present.

Data on reproduction and milk production

The dates and results of artificial inseminations (AI), the calving to conception interval, and the serial number of the successful AI were recorded. The quantity of milk produced on day $4(\mathrm{~kg})$, the quantity of milk, butterfat and milk protein $(\mathrm{kg})$ and the butterfat and milk protein percentage produced during the first 100 days of lactation and, in the case of multiparous cows, the milk production in the previous 305-day lactation $(\mathrm{kg})$ were also recorded. 
Statistical analysis

In order to select the metabolic factors predicting the risk of development of RP, the relationship between metabolic indicators measured on days -14-0 prepartum and RP was analysed by logistic regression, where each variable was examined individually in the model (Everitt and Hothorn 2006). Differences between diseased and healthy groups of cows in terms of metabolic, reproductive and milk production indicators were studied by Mann-Whitney test (Hollander and Wolfe 1999). The correlation between BCS and metabolic indicators (NEFA) was quantified by Kendall's rank correlation test (Valz and Thompson 1994), while the interrelationships of metabolic indicators (NABE-NEFA) were analysed by Pearson's correlation (Reiczigel et al. 2007). The independence between the RP and parity, viability and sex of the calf, the provision of calving assistance, puerperal metritis, subinvolution and ovarian cysts was tested by Fisher's exact test (Agresti 1990). The level of significance was set at $P<0.05$.

\section{Results}

\section{Metabolic status-retained placenta}

Twenty-one out of the 105 cows included in the study had RP (20.0\%). Of the indicators characterising energy metabolism in the two weeks (-14-0 days) before calving, NEFA concentration of the blood plasma showed a significant positive correlation with the development of RP $(P<0.05)$. A $1.0 \mathrm{mmol} / 1$ elevation of blood plasma NEFA concentration resulted in a 102-fold increase in the odds of RP development (Table 1, Fig.

Table 1. Relationship between metabolic indicators recorded between days -14-0 before calving and retained placenta (results obtained by logistic regression)

\begin{tabular}{|l|lll|}
\hline Metabolic indicators & \multicolumn{3}{|c|}{ Retained placenta } \\
\hline & OR; & $(95 \% \mathrm{CI}) ;$ & $P$ \\
\hline Plasma G $(\mathrm{mmol} / \mathrm{l})$ & $0.96 ;$ & $(0.49-1.87) ;$ & 0.90 \\
\hline Plasma AcA $(\mathrm{mmol} / \mathrm{l})$ & & $(0.00-4.25) ;$ & 0.94 \\
\hline Plasma NEFA (mmol/l) & $102.12 ;$ & $(1.51-6906.54) ;$ & $<0.05$ \\
\hline Plasma AST (U/l) & $1.00 ;$ & $(0.98-1.03) ;$ & 0.84 \\
\hline Urine $\mathrm{pH}$ & $0.81 ;$ & $(0.46-1.41) ;$ & 0.46 \\
\hline Urine NABE $(\mathrm{mmol} / \mathrm{l})$ & $0.99 ;$ & $(0.98-1.00) ;$ & $<0.05$ \\
\hline
\end{tabular}

OR: odds ratio, $\mathrm{CI}$ : confidence interval, $P$ : significance, $\mathrm{G}$ : glucose, AcA: acetoacetic acid, NEFA: non-esterified fatty acids, AST: aspartate-aminotransferase, NABE: net acid-base excretion

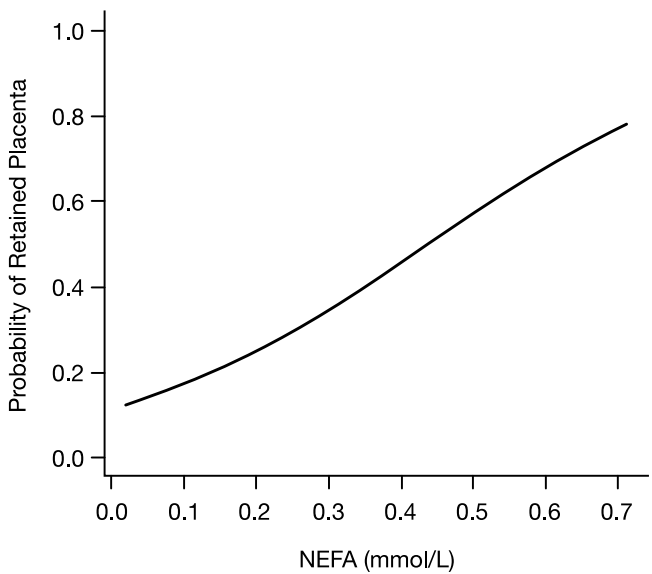

Fig. 1: Relationship between the probability of retained placenta and plasma NEFA concentration ond days - 14-0 before calving (results obtained by logistic regression), NEFA: non-esterified fatty acids
1 ). The occurrence of RP did not depend significantly on prepartum blood plasma glucose and AcA concentrations and AST activity (Table 1).

A prepartum ketonuria of at least $2+$ degree significantly increased the probability of RP (OR: Infinite; CI: 1.18 - Infinite; $P=0.038$ ).

Decrease of the BCS between days -14-0 prepartum and day 4 postpartum increased the occurrence of RP, but the correlation was not significant (OR: 1.3 ; CI: $0.43-4.2 ; P=$ $0.621)$. At the same time, for the entire period studied (days -14-0 to days 84-91) a mild positive significant correlation was demonstrated between the BCS and the NEFA concentration (tau: $0.153 ; P<0.0001)$.

Of the indicators of acidbase metabolism, urine $\mathrm{pH}$ and NABE measured on days -14-0 prepartum showed a negative correlation with the odds of RP; for NABE the correlation was significant (OR: 0.99; CI: 0.98 1.00; $P=0.032$ ) (Table 1, Fig. 2). Urine NABE and blood plasma NEFA concentration showed a significant negative correlation with each other before calving 


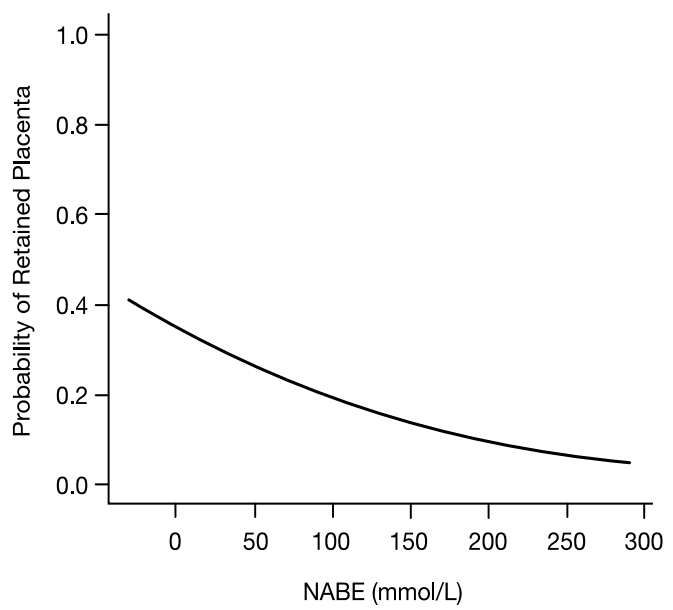

Fig. 2: Relationship between the probability of retained placenta and urine NABE concentration on days - 14-0 before calving (results obtained by logistic regression), NABE: net acid-base excretion
(Pearson's correlation: $-0.24 ; \quad P<$ $0.05)$.

The indicators characterising the energy balance (plasma glucose, AcA, NEFA, AST and BCS) and acid-base balance (urine $\mathrm{pH}, \mathrm{NABE}$ ) of $\mathrm{RP}+$ and RP- animals were not significantly different when studied on days 4, 28-35, 56-63 and 84-91 postpartum. Details are not shown here.

Animal-related and environmental factors - retained placenta

The odds of RP were not influenced significantly by parity $(P=0.85)$, sex (OR: 0.95 ; CI: $0.32-2.77 ; P=1$ ) and viability $(P=0.83)$ of the calf, and the provision of manual calving assistance (OR: 0.63; CI: $0.24-2.19 ; P=0.75$ ).

Table 2. Comparative analysis of reproductive and milk production data of cows with (RP+) or without (RP-) retained placenta

\begin{tabular}{|c|c|c|c|c|c|c|}
\hline \multirow[t]{2}{*}{ Parity } & \multicolumn{2}{|c|}{ Primiparous } & \multicolumn{2}{|c|}{ Multiparous } & \multicolumn{2}{|c|}{$\begin{array}{l}\text { Primiparous }+ \\
\text { multiparous together }\end{array}$} \\
\hline & $\begin{array}{l}\mathrm{RP}+ \\
(\mathrm{n}=6)\end{array}$ & $\begin{array}{l}\mathrm{RP}- \\
(\mathrm{n}=28)\end{array}$ & $\begin{array}{l}\mathrm{RP}+ \\
(\mathrm{n}=15)\end{array}$ & $\begin{array}{l}\mathrm{RP}- \\
(\mathrm{n}=56)\end{array}$ & $\begin{array}{l}\mathrm{RP}+ \\
(\mathrm{n}=21)\end{array}$ & $\begin{array}{l}\mathrm{RP}- \\
(\mathrm{n}=84)\end{array}$ \\
\hline Indicator & \multicolumn{6}{|c|}{ average \pm SD } \\
\hline Days to first AI & $91.6 \pm 31.0$ & $115.6 \pm 58.1$ & $101.7 \pm 30.5$ & $83.4 \pm 40.1$ & $98.5 \pm 30.0$ & $95.6 \pm 49.8$ \\
\hline $\begin{array}{l}\text { Calving to conception } \\
\text { interval }\end{array}$ & $191.0 \pm 95.9$ & $186.0 \pm 91.3$ & $163.2 \pm 100.8$ & $155.9 \pm 96.6$ & $172.5 \pm 96.7$ & $168.9 \pm 94.7$ \\
\hline $4^{\text {th }}$ day milk, $\mathrm{kg}$ & $16.8 \pm 7.0$ & $19.7 \pm 5.4$ & $24.4 \pm 6.9$ & $25.8 \pm 6.3$ & $22.2 \pm 7.6$ & $23.8 \pm 6.6$ \\
\hline 100-day milk, kg & $2926 \pm 673^{a}$ & $2350 \pm 419$ & $279 \pm 499$ & $3121 \pm 816$ & $2834 \pm 544$ & $2867 \pm 796$ \\
\hline 100-day butterfat, $\mathrm{kg}$ & $99.9 \pm 8.6$ & $90.7 \pm 23.0$ & $97.8 \pm 19.8^{\mathrm{a}}$ & $113.4 \pm 28.7^{b}$ & $98.5 \pm 19.2$ & $105.9 \pm 28.9$ \\
\hline 100-day butterfat, $\%$ & $3.5 \pm 0.7$ & $3.9 \pm 0.8$ & $3.4 \pm 0.6$ & $3.7 \pm 0.6$ & $3.5 \pm 0.6$ & $3.7 \pm 0.6$ \\
\hline 100-day milk protein, $\mathrm{kg}$ & $85.4 \pm 17.0$ & $71.4 \pm 12.8$ & $86.4 \pm 16.0$ & $94.8 \pm 26.0$ & $86.1 \pm 15.9$ & $87.1 \pm 25.0$ \\
\hline 100-day milk protein, $\%$ & $2.97 \pm 0.22$ & $3.04 \pm 0.18$ & $3.11 \pm 0.27$ & $3.04 \pm 0.2$ & $3.07 \pm 0.26$ & $3.04 \pm 0.20$ \\
\hline $\begin{array}{l}\text { Previous 305-day } \\
\text { lactation milk, kg }\end{array}$ & - & - & $7873 \pm 1791$ & $8164 \pm 1734$ & - & - \\
\hline
\end{tabular}

a, b: significant difference $P<0.05$ (Mann-Whitney test), AI: artificial insemination

\section{Retained placenta - reproductive performance}

$\mathrm{RP}$ did not exert a significant influence on whether the CL/RCL structures indicative of cyclic ovarian function could first be found on the ovaries on days 28-35, 56-63 or 84-91 postpartum. $\mathrm{RP}$ had no significant influence on the rate of re-conception (OR: 1.10; CI: 0.35 - 3.93; $P=1$ ) or on the number of services required for pregnancy. The interval from calving to first service was about 3-7 days shorter in healthy cows than in cows with RP. For the multiparous cows and for all cows taken together, the interval from calving to first service was shorter in healthy animals. At the same time, primiparous cows with RP had a longer interval from calving to first insemination. These differences were not significant (Table 2). RP did not significantly affect the occurrence of subinvolution, follicular cyst or luteal cyst (Table 3 ). At the same time, 
Table 3. Relationship between retained placenta and other reproductive disorders (results obtained by Fisher's exact test)

\begin{tabular}{|l|ccc|}
\hline Disorder & \multicolumn{3}{|c|}{ Retained placenta } \\
\hline & OR & $(95 \% \mathrm{CI})$ & $P$ \\
\hline Puerperal metritis & 27.30 & $(4.0-1176.0)$ & $<0.001$ \\
\hline $\begin{array}{l}\text { Uterine subinvolution } \\
\text { at 28-35 days }\end{array}$ & 0.77 & $(0.22-0.429)$ & 0.795 \\
\hline Follicular cyst & 0.37 & $(0.01-2.91)$ & 0.689 \\
\hline Luteal cyst & 3.66 & $(0.66-19.05)$ & 0.076 \\
\hline
\end{tabular}

OR: odds ratio

CI: confidence interval

$P$ : significance it significantly and greatly increased the odds of development of PM (OR: 27.3; CI: 4.0 - 126; $P<0.001$ ) (Table 3).

Forty-seven out of the 105 cows included in the study had PM $(44.8 \%)$.

\section{Retained placenta - milk production}

The effect exerted by RP on milk production was inferred from the comparison of $\mathrm{RP}+$ and RP- groups. During the data analysis, primiparous and multiparous cows were evaluated both separately and collectively (Table 2 ). Milk production $(\mathrm{kg})$ on day 4 postpartum of both primiparous and multiparous RP+ cows was lower than that of the RP- animals, but the difference was not significant. The milk production $(\mathrm{kg})$ during the first 100 days of lactation of primiparous RP- cows was lower than, while that of the multiparous RP- cows exceeded that of the RP+ animals. For the primiparous cows the difference was significant $(P<0.05)$. Collective evaluation of the groups did not demonstrate significant differences in the 100 -day milk production. The 100 -day butterfat $\%$ of RP- cows was $0.2-0.4 \%$ higher than that of the RP+ animals, but the difference was not significant. As compared to RP+ cows, primiparous RP- cows had a lower, while multiparous RP- cows a higher, 100-day butterfat production; in this case the difference was significant for the multiparous cows $(P<0.05)$. Collective evaluation of the primiparous and multiparous cows did not reveal a significant difference between RP- and RP+ cows in 100-day butterfat production.

In milk protein production there was no major difference between the RP- and the RP+ groups. For the 100-day milk protein $\mathrm{kg}$ and milk protein $\%$ similar trends were observed as for milk and butterfat production (Table 2).

\section{Discussion}

NEB developing at the end of gestation markedly increased the odds of developing RP. Elevated plasma NEFA concentration and $\geq 2+$ ketonuria measured on days $-14-0$ prepartum are in all probability suitable metabolic indicators for characterising the increased risk of RP because of NEB. The acidotic shift in acid-base balance before calving was indicated by the decreasing NABE in the urine. This acidotic shift might also have contributed to the prepartum development of NEB, which is supported by the significant negative correlation found between plasma NEFA and urine NABE. It is known that the amount of energy available for the body depends, besides dry matter intake, on the rumen microflora (Grummer 1995) and on adaptive changes of the ruminal epithelium determining the utilisation, which depend on the acid-base status (Dirksen et al. 1999). In the last two weeks before calving, the decreasing urinary NABE in itself indicated the increasing risk of development of RP. Prepartum feed rich in starch and concentrate and poor in fibre increases the risk of ruminal acidosis (Brydl 1995) and, consequently, NEB (Holtenius et al. 2003). The conclusion presents itself that although at the end of gestation the dry matter intake decreases also under physiological conditions (Bertic s et al. 1992), factors negatively affecting dry matter intake and/or disturbing the process of ruminal adaptation increase the chance of development of prepartum NEB and, consequently, RP. In addition to nutrition inducing ruminal acidosis, further risk factors may include overcondition (Hayirli et al. 2002), numerous management failures, certain environmental factors such as discomfort (Grummer et al. 2004) or heat stress (De Rensis and Scaramuzzi 2003). 
The course of the solving of the junction between maternal and foetal placenta starts about two weeks before parturition. The phagocytic and resorptive capacity of polymorphonuclear $(\mathrm{PMN})$ neutrophils present in the crypts plays an important role in this mechanism. Decreased neutrophil function is one of the possible causes of RP (Kimura et al. 2002). The NEB manifested in increased plasma levels of NEFA and beta-hydroxybutyrate impair the migration, phagocytic and killing activity and/or the oxidative burst of PMN and other leukocytes (Goff 2003; Sartorelli et al. 1999, 2000; Suriyasathaporn et al. 2000; Zerbe et al. 2000).

When studied alone, RP usually exerted a negative influence on the reproductive indices but significant correlations were not found, which is consistent with the findings reported by other authors (Muller and Owens 1974; Coleman et al. 1985; Halpern et al. 1985; Kaneko et al. 1997). In our study - in agreement with others (Paisley et al. 1986; Hussian 1989; Levis 1997; Sheldon and Dobson 2004; Han and Kim 2005) - the RP presents an outstanding risk for the development of PM. Therefore, the negative effects of RP may become significant primarily because of their role in facilitating the development of PM, rather than on their own (Stevenson and Call 1988; Laven and Peters 1996; Han and Kim 2005; Könyves et al. 2009) The odds of the development of ovarian cysts was not affected by RP which is consistent with previous reports (Gröhn and Rajala-Shultz 2000; Han and Kim 2005). However, Erb et al. (1985) found an indirect association between the occurrence of ovarian cysts and retained placenta mediated by endometritis.

Our finding that the odds of developing RP were not affected substantially by parity, is consistent with some (Han and Kim 2005) but not other previous studies (Curtis et al. 1985; Erb et al. 1985; Gröhn et al. 1990; Correa et al. 1993) which reported an increased incidence of RP with advancing parity. The relatively low sample size could be a possible explanation of our findings. In our study the manual calving assistance did not increase the risk of RP. An explanation may be the appropriate assistance practice performed in the examined herd. Similar results were reported by Curtis et al. (1985) as veterinary assisted dystocia was not associated with higher incidence of RP.

The effects exerted on milk production are not explicit either. An explanation of the modest influences exerted on the reproductive and production indices may be that at the early stage of lactation studied by us RP did not significantly affect the metabolic status. However, others reported that RP is a predisposing factor for metabolic disorders in dairy herds (Curtis et al. 1985; Markusfield 1986; Han and Kim 2005). The NEB manifested in elevated plasma NEFA in the first 30 days of lactation predisposes to the delayed anatomic involution of the uterus (Könyves et al. - in press). The indirect negative effect of RP on milk yield mediated by puerperal metritis is reported by Könyves et al. (2009).

In conclusion, the odds of developing RP markedly increased in cows developing NEB and showing an acidotic shift in acid-base balance before calving. On days $-14-0$ prepartum, the elevated plasma NEFA concentration and $\geq 2+$ ketonuria indicative of NEB and the decreasing urinary NABE suggestive of the acidotic shift of acid-base balance are metabolic indicators highly suitable for characterising the risk of development of RP. RP in itself did not markedly affect the metabolic status between days 4 and 84-91 of lactation, nor did it influence reproductive performance and milk production in the given lactation. RP greatly increased the odds of development of puerperal metritis.

\section{Hodnocení rizika retence placenty a jejích důsledků pro stav dělohy, reprodukci a mléčnou užitkovost dojnic}

Cílem této studie bylo stanovení metabolických ukazatelů charakterizujících energetický metabolismus a acidobazickou rovnováhu dojnic pro zhodnocení zdravotního rizika spojeného s retencí placenty (RP). Zjištěna byla spojitost mezi RP a různými analyzova- 
nými faktory, podobně jako vliv RP na vývoj puerperální metritidy (PM), na reprodukci a produkci mléka. Pro metabolické testy bylo vybráno celkem 105 holštýnsko-fríských krav, jimž byly odebírány vzorky krve v intervalech vyjádřených ve dnech před/po porodu: -14-0 prepartum, 4.den po porodu, $10-14,28-35$, 56-63 a 84-91 po porodu. Od 4. dne po porodu provázelo odběr vzorků krve pro metabolické ukazatele i klinické vyšetření diagnostiku involuce dělohy popř. metritidy, a následně od období 28-35. dne p.p. byla taktéž ultrasonograficky sledována aktivita vaječníků. V předporodním období $-14-0 \mathrm{se}$ přímo úměrně zvýšila koncentrace nenasycených mastných kyselin (NEFA) v krevní plasmě s pozitivní pravděpodobností výskytu RP (OR) 102.1, $P<0.05$; zatímco acidobazický výluček moči (NABE) vykazoval ve vztahu k RP zápornou korelaci (OR 0.99; $P<0.05)$. NEFA je nepř́mo úměrná NABE (Pearsonův koeficient: $0.24 ; P<0.05$ ). Přítomnost ketonů $\mathrm{v}$ moči dosahující úroveň $\geq 2+$ zvyšovala pravděpodobnost $\mathrm{RP}(\mathrm{OR}: \infty ; P<0.05)$. V předporodním období -14-0 signalizují zvýšené riziko zadržení placenty pozměněné ukazatele jako je zvýšená plasmatická koncentrace nenasycených mastných kyselin (NEFA), nižší hodnota acidobazického výlučku moči (NABE) a ketonurie $\geq 2+$. Pravděpodobnost výskytu RP nebyla ovlivňována paritou matky, pohlavím nebo životností mlád'at, ani přítomností odborné asistence u porodu. Retence placenty zvýšila riziko vzniku puerperální metritidy (OR: 27.3; $P<0.0001)$. V této studii nebyl prokázán vliv RP na metabolické ukazatele, reprodukční potenciál ani produkci mléka u dojnic.

\section{References}

Agresti A 1990: Categorical data analysis. Wiley, New York, pp. 59-66

Becze J, Perjés I 1981: A sertés szarvasmarha szaporítása és annak közgazdasági kérdései a nagyüzemi termelésben (in Hungarian, Cattle reproduction and its economical relations in large scale production). Mezőgazdasági Kiadó, Budapest

Bertics SJ, Grummer RR, Cadorniga-Valino C, Stoddard EE 1992: Effect of prepartum dry matter intake on liver triglyceride concentration and early lactation. J Dairy Sci 75: 1914-1922

Brydl E 1995: Prevention of metabolic disorders of dairy cows by multi-phase feeding strategy during the peripartal period. Hungar Vet J 50: 718-720

Brydl E, Jurkovich V, Könyves L, Tegzes L, Kálmán I 2003: Occurrence of subclinical metabolic disorders on dairy farms in Hungary in 2001. Magy Állatorv Lapja 125: 393-400

Brydl E, Könyves L, Tegzes L, Jurkovich V, Tirián A 2008: Incidence of subclinical metabolic disorders in Hungarian dairy herds during the last decade. Magy Állatorv Lapja 130 (Suppl. I): 129-134

Coleman DA, Thayne WV, Dailey RA 1985: Factors affecting reproductive performance of dairy cows. J Dairy Sci 68: 1793-1803

Correa MT, Erb HN, Scarlett J 1993: Path analysis for seven postpartum disorders of Holstein cows. J Dairy Sci 76: $1305-1312$

Curtis CR, Erb HN, Sniffen CJ, Smith RD, Kronfeld DS 1985: Path analysis of dry period nutrition, postpartum metabolic and reproductive disorders, and mastitis in Holstein cows. J Dairy Sci 68: 2347-2360

De Rensis F, Scaramuzzi RJ 2003: Heat stress and seasonal effects on reproduction in the dairy cow - a review. Theriogenology 60: 1139-1151

Dirksen GH, Liebich HG, Mayer E 1999: Adaptive changes of the ruminal mucosa and their functional and clinical significance. Bov Pract 20: 116-120

Erb HN, Smith RD, Oltenacu PA, Guard CL, Hillman RB, PowerS PA, Smith MC, White ME 1985: Path model of reproductive disorders and performance, milk fever, mastitis, milk yield and culling in Holstein cows. J Dairy Sci 68: 3337-3349

Everitt B, Hothorn T 2006: A handbook of statistical analyses using R. Chapman and Hall/CRC, Boca Raton, FL, $542 \mathrm{p}$.

Goff JP 2003: Managing the transition cow - considerations for optimising energy and protein balance and immune function. Cattle Pract 11: 51-63

Gröhn YT, Erb HN, McCullogh CE, Saloniemi HS 1990: Epidemiology of reproductive disorders in dairy cattle: among host characteristics, disease and production. Prev Vet Med 8: 25-39

Gröhn YT, Rajala-Shultz PJ 2000: Epidemiology of reproductive performance in dairy cows. Anim Reprod Sci 60/61: 605-614

Grummer RR 1995: Impact of changes in organic nutrient metabolism on feeding the transition dairy cow. J Anim Sci 73: $2820-2833$

Grummer RR, Mashek DG, HayIrli A 2004: Dry matter intake and energy balance in the transition period. Vet Clin N Am-Food Anim Pract 20: 447-470 
Halpern NE, Erb HN, Smith RD 1985: Duration of retained membranes, and subsequent fertility in dairy cows. Theriogenology 23: 807-813

Han IK, Kim IH 2005: Risk factors for retained placenta and the effect of retained placenta on the occurrence of postpartum diseases and subsequent reproductive performance in dairy cows. J Vet Sci 6: 53-59

Harrison JP, Hancock DD, Conrad HR 1984: Vitamin E and selenium for reproduction in the dairy cow. J Dairy Sci 67: 123-129

Hayirli A, Grummer RR, Nordheim EV, Crump PM 2002: Animal and dietary factors affecting feed intake during the prefresh transition period in Holsteins. J Dairy Sci 85: 3430-3443

Hidiroglou MA, MCALlister AJ, Williams CJ 1987: Prepartum supplementation of selenium and vitamin E to dairy cows: assessment of selenium status and reproductive performance. J Dairy Sci 70: 1281-1286

Hollander M, Wolfe DA 1999: Nonparametric statistical methods. $2^{\text {nd }}$ ed. John Wiley and Sons, New York, 787 p.

Holtenius K, Agenas S, Delavaud C, Chilliard Y 2003: Effects of feeding intensity during the dry period. 2. Metabolic and hormonal responses. J Dairy Sci 86: 883-891

Hussian AM 1989: Bovine uterine defence mechanisms: a review. J Vet Med Ser B-Infect Dis Vet Public Health 36: $641-651$

Huszenicza Gy, Kulcsár M, Dieleman SJ, Nikolic JA, Jánosi Sz, Kóródi P, Bartyik J, Ribiczei-Szabó P, Rudas P 1998: Endocrine alterations and resumption of cyclic ovarian function in dairy cows affected by various forms of hyperketonaemia in early weeks of lactation. In: Wensing T (Ed.): Production diseases in farm animals. Book of abstracts of $10^{\text {th }}$ International conference, 24-28 August. Wageningen Press, Utrecht, The Netherlands, p. 239

Huszenicza Gy, Kulcsár M, Rudas P 2002: Clinical endocrinology of thyroid gland function in ruminants. Vet Med-Czech 47: 199-210

Ingvartsen KL 2006: Feeding- and management-related diseases in the transition cow. Physiological adaptations around calving and strategies to reduce feeding-related diseases. Anim Feed Sci Technol 126: 175-213

Jorritsma R, Wensing T, Kruip TAM, Vos PL, Noordhuizen JPTM 2003: Metabolic changes in early lactation and impaired reproductive performance in dairy cows. Vet Res 34: 11-26

Kaneene JB, Miller R 1995: Risk factors for metritis in Michigan dairy cattle using herd- and cow-based modelling approaches. Prev Vet Med 23: 183-200

Kaneko K, Kawakami S, Miyoshi M, Abukawa T, YamanAka S, MocHizuki M, Yoshihara S 1997: Effect of retained placenta on subsequent bacteriological and cytological intrauterine environment and reproduction in Holstein dairy cows. Theriogenology 48: 617-624

Kimura K, Goff JP, Kehrli ME, Reinhardt TA 2002: Decreased neutrophil function as a cause of retained placenta in dairy cattle. J Dairy Sci 85: 544-550

Könyves L, Szenci O, Jurkovich V, Tegzes L, Tirián A, Solymosi N, Gyulay Gy, Brydl E 2009: Risk assessment of postpartum uterine diseases and consequences of puerperal metritis for subsequent metabolic status, reproduction and milk yield in dairy cows. Acta Vet Hung 57: 155-169

Könyves L, Szenci O, Jurkovich V, Tegzes L, Beckers JF, Brydl E 2009: Examination of some reproductive indices of peripartal period in relation with energy metabolism in dairy cows. Magy Állatorv Lapja (in press)

Kutas F 1965: Determination of net acid-base excretion in the urine of cattle. Acta Vet Acad Sci Hung 15: 147153

Laven RA, Peters AR 1996: Bovine retained placenta: aetiology, pathogenesis and economic loss. Vet Rec 139: 465-471

Lewis SG 1997: Uterine health and disorders. J Dairy Sci 80: 984-994

Maizon DO, Oltenacu PA, Gröhn YT, STrawderman RL, Emanuelson U 2004: Effects of diseases on reproductive performance in Swedish Red and White dairy cattle. Prev Vet Med 66: 113-126

Markusfield O 1986: The association of displaced abomasum with various periparturient factors in dairy cows. Prev Vet Med 4: 173-183

Miller JK, Brzezinska-Slebodzinska E, Madsen FC 1993: Oxidative stress, antioxidants, and animal function. J Dairy Sci 76: 2812-2823

Muller LD, Owens MJ 1974: Factors associated with the incidence of retained placentas. J Dairy Sci 57: 725-728

Mulligan FJ, O'Grady L, Rice DA, Doherty ML 2006: A herd health approach to dairy cow nutrition and production diseases of the transition cow. Anim Reprod Sci 96: 331-353

MULVANY P 1977: Dairy cow condition scoring. NIRD paper No. 4468. NIRD Reading, Shinfield, 4 p.

Opsomer G, Grohn YT, Hertl J, Coryn M, Deluyker H, de Kruif A 2000: Risk factors for post partum ovarian dysfunction in high producing dairy cows in Belgium: a field study. Theriogenology 53: 841-857

Paisley LG, Mickelsen WD, Anderson PB 1986: Mechanisms and therapy for retained fetal membranes and uterine infections of cows: a review. Theriogenology 25: 353-381

Reiczigel J, Harnos A, Solymosi N 2007: Biostatistics for non statisticians. Pars Ltd., Nagykovácsi. Hungary, 455 p.

Sartorelli P, Paltrinieri S, Agnes F 1999: Non-specific immunity and ketone bodies. I. In vitro studies on chemotaxis and phagocytosis of ovine neutrophils. J Vet Med Ser A-Physiol Pathol Clin Med 46: 613-619 
Sartorelli P, Paltrinieri S, Comazi S 2000: Non-specific immunity and ketone bodies. II. In vitro studies on adherence and superoxide anion production in ovine neutrophils. J Vet Med Ser A-Physiol Pathol Clin Med 47: $1-8$

Suriyasathaporn W, Heuer C, Noordhuizen-Stassen E, Schukken YH 2000: Hyperketonaemia and the impairment of udder defence: a review. Vet Res 31: 397-412

Sheldon IM, Dobson H 2004: Postpartum uterine health in cattle. Anim Reprod Sci 82/83: 295-306

Sheldon IM, Lewis GS, LeBlanc S, Gilbert RO 2006: Defining postpartum uterine disease in cattle. Theriogenology 65: $1516-1530$

Stevenson JS, Call EP 1988: Reproductive disorders in the periparturient dairy cow. J Dairy Sci 71: 2572-2583

Stowe HD, Thomas JW, Johnson T, Marteniuk J, Morrow DA, Ullrey DE 1988: Responses of dairy cattle to longterm and short-term supplementation with oral selenium and vitamin E1. J Dairy Sci 71: 1830-1839

Thatcher WW, Bilby TR, Bartolome JA, Silvestre F, Staples CR, Santos JE 2006: Strategies for improving fertility in the modern dairy cow. Theriogenology 65: 30-44

Trinder N, Hall RJ, Rentan CP 1973: The relationship between the intake of selenium and vitamin E on the incidence of retained placentae in dairy cows. Vet Rec 93: 641-643

Valz PD, Thompson ME 1994: Exact inference for Kendall's S and Spearman's Rho. with extensions to Fisher's exact text $\mathrm{r}$ x c contingency tables. J Comput Graph Stat 3: 459-472

Zamet CN, Colenbrander VF, Erb RE, Callahan CJ, Chew BP, Moeller NJ 1979: Variables associated with peripartum traits in dairy cows. II. Interrelationships among disorders and their effects on intake of feed and on intake on reproductive efficiency. Theriogenology 11: 245-260

Zerbe H, Schneider N, Leibold W, Wensing T, Kruip Tam, Schuberth HJ 2000: Altered functional and immunophenotypical properties of neutrophil granulocytes in postpartum cows associated with fatty liver. Theriogenology 54: 771-786 